\title{
INTERVIEW WITH \\ Rhacel Salazar Parreñas
}

\author{
INTERVIEW CONDUCTEd By \\ Melissa Freiburger and Liz Legerski
}

Prepared By

LIZ LEGERSKI

STAR: How did you get interested in what you are studying? Did personal experience drive your research agenda?

Parreñas: I was always interested in the issues of immigrant women. And I think it was my personal experience as a migrant. But it was looking at my mother's experiences and my aunts' experiences. So when I was growing up in Boston my mother worked as a hotel housekeeper at the Charles Hotel in Cambridge, Massachusetts, and her sisters were nannies in New York. They had been raised in a very upper-class household in the Philippines. My mother has a Ph.D. My other aunts are also educated, one is actually a concert pianist, and one has a Master's in education. So then, I guess it was always this puzzle for me- how they cope with their experience of downward mobility. That was always a question in my head that I think motivated me to go where I ended up going in my research, which is looking at the labor of immigrant women as well as other social issues that extend from the labor of immigrant women. I look not so much at issues of migrant communities but instead issues of the family generally, and the relationship of immigrant women with children, their incorporation vis-à-vis the state, and how that defines their labor.

STAR: Did you find any resistance to that or did you find mentors that really supported you in that? 
Parreñas: I think that it was probably a good thing that I went to Berkeley for my undergraduate degree because I ended up finding this obscure major called Peace and Conflict Studies. It was a fairly new bachelor's degree. It is an interdisciplinary degree. The major basically looks not just at world peace, but the definition of world peace for the major includes social equality. So peace can only be achieved if everyone is truly equal. And so, with that in mind, I focused my studies on understanding the issues of immigrant women. When I was an undergrad all the courses I took were related to the experiences of immigrant women. That was kind of interesting that I was allowed to do that. Then it just continued into graduate school.

STAR: A lot of your work focuses on the Filipina experience of migration and globalized carework. So what would you say makes the Filipina experience either unique or similar to other groups of workers or women?

Parrñas: The Philippines is a good representative case of domestic work as an occupation that defines relations between the First and the Third World, particularly with women, because Filipinas migrate to 160-plus countries and destinations. So they end up not just in the Americas, specifically Canada and the US, but also all over Western Europe and all over Asia, West Asia included, as well as various territories of the US like Saipan, et cetera, et cetera. They are everywhere. Their global dispersion emphasizes the extent of First and Third World care work inequalities. But their case is also quite different in that most of them are educated women, unlike other domestics from mostly Latin American countries and what we would consider as representative origins of domestic workers in the US, such as Mexico, and El Salvador. And in a lot of the literature we see that most of the women are not educated, so it really differentiates the migrant experience of Filipinas. So the whole issue of class and loss of class status, having to negotiate your declining class status is something that is not necessarily shared by other immigrant women that are discussed in the literature of gender and migration. That makes Filipinas unique in some way. However, there are also now a lot of groups of domestic workers who are 
also educated like Filipinas; Peruvians also have a high level of educational attainment. A lot of the Eastern European domestics have a high level of educational attainment, so they are actually becoming more normative now.

STAR: Tomorrow you will be talking about global-local change and studying that. How do you define that? What are some of the methodological concerns when you study global-local change?

Parreñas: That's a question I still haven't figured out, but I am going to try to figure it out by tonight [laughter]. When Joane asked me to look at that, global-local change, I had to pause because from the top of my head it's really hard to say. First I didn't even realize that I studied that, but she told me I studied that, so I said, 'ok, I guess I study it' [laughter]. How do I begin to address this question? I think that when I do my work I always situate the subjects that I look at within larger global processes. While I look at them as individuals who are their own persons, and they make their own decisions, I recognize that everything they do takes place within a larger context. I think that's why I like the work of Michel Foucault, because the subject's always being constituted by external forces. Some people think that that's overly deterministic, that it removes the agency of the individual. But I don't really think it removes their agency. I think their actions constitute the structures that shape them. I don't know if that really answers your question, but I always look at individual actions as constituted by larger social processes and I think that's why in my work the global and the local are always together and they are not separate processes. When people study gender and globalization, people advocate that you can't really see gender unless you look at global processes and I don't really agree with that. So in my talk later I am going to say how the macro process of globalization is in itself gendered. So that's what I am going to try to establish, hopefully I am convincing [laughter]. But you can't really separate the macro and micro or the local and global. Local processes happen because of global processes occurring. Our task then, as sociologists, is to figure out methods and frameworks for showing how they are indeed embedded. This is like the public and private divide that we still can't 
seem to get away from, but everyone knows the private and public are quite intertwined.

STAR: What kinds of methodological concerns or even ethical concerns come up when doing the kind of qualitative work that you do when interviewing women?

Parreñas: There are a lot of ethical issues that I face. First, one of the biggest ones I think, and many people have talked about this, many people have written about it-I haven't written about it, but I can relate to things I have read about similar to this experience- which is you are taking something from the community and you are not giving something back. It's not the individual per se. What you're gaining collectively from the group makes you advance in your career and none of them get anything from you, either individually or collectively. So then, you can say, 'oh well, I'm letting people know about their experiences and that's my indirect way of justifying it.' But I've also then felt compelled to volunteer in non-profit organizations while I'm doing fieldwork. So I'm not necessarily directly giving back to the person I am interviewing, but I achieve this sense that I'm giving back something to the community that I am studying. So I have done things like volunteer in schools or volunteer for different organizations. Some people feel compelled to share their research with their community and that's the way that they give back. I haven't done that. I haven't thought of doing that. So people do it in many different ways. But I think it's important to have this consciousness that your career gain is something that, it's a huge favor that they're giving you, so how do you give back to them? So individually I always give them presents. But I interviewed Filipinas and that's just a cultural thing. So I just give them a token gift like shampoo from the US. They love that. Like any products, like St. Ives Apricot Scrub. That's like a huge thing for them.

STAR: Do you ever get the sense that just speaking about their experiences gives them something, that it's empowering them somehow, or that it feels good that someone is interested in their life? 
Parreñas: No, whenever I'm interviewing them I feel like I'm taking their time away. Then I feel really guilty, and I feel like, "God, I bet you they'd rather be doing something else [laughter]." I always think that. So I feed them, that's another thing I do, so then I don't feel so guilty. But there is always this conscious guilt I have. Because my feeling is why would they want to spend time with me? And it's exhausting to talk about your life. But then a lot of times after the interview, they say, 'oh, this is actually a lot of fun, this actually felt good, like it helped me to think about my situation in another way that I've never done before.' So you do sometimes get social acceptance from them and they let you know that they've appreciated the time they spent with you. But not all do. I really assume this when I am doing an interview: "oh God, I'm taking their time away - they could be making money right now working, but instead I'm interviewing them." But I honestly don't know if they feel the way I do. But I can't help it. It's taking their time away. ... You don't want to impose too much on them. I definitely don't think it's a favor to them that I'm talking to them. It's definitely a favor to me. And it's hard to negotiate, how do I adequately give back for what I'm gaining? That's always a question I have.

STAR: One of the criticisms of the care chain concept is that it narrowly focuses on one group of migrants - domestics. Do you think there is limited utility in the care chain idea, or do you think we can expand this model to include other kinds of workers and other kinds of migration patterns?

Parreñas: The care chain idea really begins from this notion of women's shared experience of gender inequality. In this case it is the responsibility for care work. That's the premise of it, that women share gender inequality. But women at the same time have different privileges when it comes to race and class. And so I think that if you look at it that way, the responsibility for care no longer is a universal experience that women share as it is also a source of inequality between them. This is because people pass on their care burdens to those who are less privileged then them. So I think that if you frame it in the context of looking at care inequality, then I 
think you can expand it a bit. So it's not just the actual carework, but I think there's many inequalities in society that before weren't commodified and now you commodify it. And it could include education and teachers that we now recruit from the Third World.

STAR: Where do you see this area of research going? It seems to be expanding and being developed from a range of disciplines. Where would you like to see it go? Or where are you headed next with this idea?

Parreñas: One big question for me is how we think of the First and Third Worlds - the way we look at relationships between nation-states - needs to be changed a bit. Because I think the international division of reproductive labor tells us it's only one group of women from each particular nation-state that participates in it. And so then there are all these other groups that are not in it. What about women of color here who can't afford paid nannies? What about nannies in the Third World who can't afford to go abroad? What about those kinds of feminine-gendered individuals that are not in the picture? It makes me think that we have to reformulate our binary conception of First and Third World inequities which is what the international division of reproductive labor is based on. It assumes that there is the First and Third World. It does exist, except that this construction also tells us that it's not a complete construction because of all the people who are missing from the equation. I think a huge thing is that the rich people in Third World and the poor people in the First World is what is missing. I think that there is this class of global upper-class professionals, the rich people in the US and the rich people in the Philippines. I don't think that they are that far from each other any more. Of course, you get privileges of the state. If your state is richer then your life is better; if you're poor in the US your life is better than if you're poor in the Philippines. However, I think that we do need to reconstitute our constructions of inequality across nation-states and have a better framework for understanding how the rich in the Philippines are not so different from the rich in the US. Because a lot of the rich people in the Philippines go to the US and bring their Filipina domestics with them. So you could say that they are 
then part of that care chain with them on the top. So it's not really divided by race, I think, as it implies. I think class and gender and citizenship are huge issues. But you can have global citizenship if you have money, right?

STAR: You've successfully secured funding from places like the NSF, the Ford Foundation, and the Rockefeller Foundation. What kind of advice would you give to graduate students or young faculty who are interested in working with these funding institutions?

Parreñas: I think originality of projects always helps. To come up with questions that no one else has asked is very good. Being meticulous is very good, like with your methods you have to be very meticulous. It helps, but you also just have to love what you're doing. That's what I always say. You have to love what you're doing because then it just comes out in your grant that you meant to do what you say you want to do. But it has to be feasible, of course. But I really think it's really the originality, because you get your comments back sometimes and you think, oh. I now recognize the questions that get the review panel excited. The questions you bring up are very important. And they don't have to be a causal type of question where you have a hypothesis. They could also be open-ended questions. But you have to be conscious that you are doing that and let them know.

STAR: Having your research agenda develop from your personal experience - what are the advantages and disadvantages or difficulties of being emotionally connected to what you do?

Parreñas: See, I was never emotionally connected to what I do [laughter]. I'm not, it's funny. I always look at it as a scientific endeavor or fact-finding. I think it's just a genuine curiosity of understanding the experience in itself, not necessarily out of an emotional commitment to it. More like, it's a political commitment to share knowledge about an understudied group.

STAR: So on that note, do you have a solution or something that you would like to see happen with this international transfer of care taking and the social policies in place? 
Parreñas: I think one of the things that I have always advocated for is to allow the kids of the women migrants to come along with them. And if they choose not to come along with them then at least we know it's been their choice to be separated in transnational household structures. But right now the problem is kids don't have a choice to join their mothers. So then it's quite ironic, a mother takes care of someone else's kid while they can't take care of their own. So I think it should be instituted that the kids should be allowed to visit their mothers. And I think paid holidays are important for the mothers because then they can go home. A lot of times the women are not paid, especially the contract-based workers, not the live-in workers; it's really hard for them to get a holiday pay because they are not working for one employer but for many different employers.

STAR: So do you think the best way to do that is through state policy?

Parreñas: Yes, I think state policies, like immigration policies, should definitely recognize the contribution of their migrant work force more than they do at the moment. I think one of the huge issues of the care chain is the human rights violations of migration laws - which basically ban family reunification. This is more stringent in Asian countries like Singapore, where the domestic workers can't even get pregnant or Taiwan where the kids can't visit the mother. In the US if the kid gets a visa then, yeah, they can visit their mother, but the chance that they all get a visa is low. So I think laws should be more humane and recognize the right of domestic workers to have a family life, which it doesn't at the moment.

STAR: Well, thank you for your time.

Parreñas: Thank you. 